\title{
PENGARUH EKSTRAK THYME (Thymus vulgaris) TERHADAP IL-6 DAN HITUNG KUMAN PADA HEPAR MENCIT Balb-c YANG DIINFEKSI METHICILLIN RESISTANT Staphylococcus aureus (MRSA)
}

\section{EFFECT OF Thymus vulgaris EXTRACT ON LEVEL IL-6 AND BACTERIAL COUNT IN LIVER IN Balb-c MICE INFECTED BY METHICILLIN RESISTANT Staphylococcus aureus (MRSA)}

\author{
Galuh Yulieta Nitihapsari ${ }^{1}$, Lisayani ${ }^{2}$, Helmia Farida ${ }^{3}$, Muchlis Achsan Udji Sofro ${ }^{4}$ \\ ${ }^{I}$ Departemen Mikrobiologi, Fakultas Kedokteran Universitas Jenderal Soedirman. \\ Jalan Dr. Gumbreg Nomor 1 Mersi Purwokerto \\ ${ }^{2}$ Rumah Sakit Pantiwilasa Dr. Cipto Semarang. \\ Jalan Dr. Cipto Nomor 50 Semarang \\ ${ }^{3}$ Departemen Mikrobiologi, Fakultas Kedokteran Universitas Diponegoro. \\ Jalan Prof. Soedarto Tembalang Semarang \\ ${ }^{4}$ Departemen Ilmu Penyakit Dalam RS Dr. Kariadi Semarang-Fakultas Kedokteran \\ Universitas Diponegoro. \\ Jalan Dr. Soetomo Nomor 16 Randusari Semarang
}

\begin{abstract}
ABSTRAK
Meningkatnya fenomena resistensi bakteri, yaitu Metisilin-Resisten Staphylococcus aureus (MRSA), mendorong pentingnya penggalian bahan alam yang memiliki efek antibakteri atau yang memodulasi respon imun. Thymus vulgaris (TV) atau herba timi diketahui memiliki efek antimikroba dan immunomodulator, sehingga diharapkan dapat mengatasi infeksi MRSA melalui peningkatan sitokin IL-6. Efek ekstrak Thymus vulgaris terhadap IL-6 dan hitung kuman pada hepar mencit balb-c yang diinfeksi MRSA diuji pada penelitian ini. Desain penelitian adalah post test only control group design. Populasi studi menggunakan 30 ekor mencit balb-c jantan yang diinfeksi MRSA dan dibagi secara acak dalam enam kelompok. Kelompok penelitian dibagi menjadi enam, yaitu kelompok K1 (mencit diinfeksi MRSA tanpa diterapi), P1 (mencit diterapi ekstrak Thymus vulgaris, 7 hari kemudian diinfeksi MRSA), K2 (mencit diinfeksi dan diterapi vankomisin), P2 (mencit diinfeksi dan diterapi ekstrak TV + vankomisin), K3 (mencit diinfeksi dan diterapi amoksisilin), dan P3 (mencit diinfeksi dan diterapi ekstrak TV + amoksisilin). IL-6 diukur dengan ELISA, hitung kuman dinilai dengan kultur mikrobiologi. Data dianalisis dan diolah menggunakan uji hipotesis dengan uji $t$-test independent program SPSS 22.0. Hasilnya ditemukan kadar IL-6 yang tidak bermakna antara kelompok K1-P1 $(p>0,05), \mathrm{K} 2-\mathrm{P} 2(p>0,05)$, dan K3-P3 $(p>0,05)$. Penurunan hitung kuman bermakna pada kelompok K1-P1 $(p<0,05)$, tidak bermakna pada K2-P2 $(p>0,05)$ dan K3-P3 ( $p>0,05)$. Kadar IL-6 dengan penurunan hitung kuman MRSA di hepar memiliki korelasi positif yang sangat lemah $(\mathrm{r}=0,086)$. Ekstrak Thymus vulgaris terbukti efektif dalam menurunkan hitung kuman MRSA pada kelompok yang tidak mendapatkan antibiotik tetapi tidak terbukti meningkatkan kadar IL-6.
\end{abstract}

Kata kunci : hitung kuman, IL-6, MRSA, Thymus vulgaris 


\begin{abstract}
The increasing phenomenon of bacterial resistance, namely Methicillin-Resistant Staphylococcus aureus (MRSA), encourages the importance of extracting natural substances that have anti-bacterial effects or which modulate immune responses. Thymus vulgaris (TV) or herbal thyme is known to have antimicrobial and immunomodulatory effects, so it is expected to overcome MRSA infection through increased IL-6 cytokines. The effect of Thymus vulgaris extract on IL-6, and bacterial counts on the liver of balb-c mice infected by MRSA tested in this study. The study design was Post-test only control group design. The population of the study was used 30 male balb-c mice infected with MRSA and randomly divided into six groups. The study group divided into 6 groups; K1 group (mice infected by MRSA without being treated), P1 (mice treated with Thymus vulgaris extract 7 days later infected with MRSA), K2 (mice infected and treated with vancomycin), P2 (mice infected and treated with TV + vancomycin extract), K3 (mice infected and treated with amoxicillin), and P3 (mice infected and treated with TV + amoxicillin extract). IL-6 was measured by ELISA, the bacterial count was assessed by microbiological culture. Data were analyzed and processed using hypothesis testing with an independent t-test program SPSS 22.0. The results showed that IL-6 levels were not significant between groups K1$\mathrm{P} 1(p>0.05)$, K2-P2 $(p>0.05)$, and K3-P3 $(p>0.05)$. The decrease in bacterial count was significant in the K1-P1 group ( $p<0.05)$, not significant in K2-P2 $(p>0.05)$ and K3-P3 $(p>0.05)$. The level of IL-6 with a decrease in MRSA count in the liver has a very weak positive correlation $(\mathrm{r}=0.086)$. Thymus vulgaris extract was proven to be effective in reducing MRSA counts in groups that did not get antibiotics but were not proven to increase IL-6 levels.
\end{abstract}

\title{
Keywords : bacterial count, IL-6, MRSA, Thymus vulgaris
}

Penulis Korespondensi:

Galuh Yulieta Nitihapsari

Departemen Mikrobiologi, Fakultas Kedokteran, Universitas Jenderal Soedirman, Purwokerto

Jalan Dr. Gumbreg Nomor 1 Mersi Purwokerto

Email: galuh.nitihapsari@unsoed.ac.id

\section{PENDAHULUAN}

Angka kejadian penyakit yang disebabkan Staphylococcus aureus mengalami peningkatan dalam beberapa tahun terakhir dan merupakan salah satu penyebab tingginya angka kematian di beberapa negara berkembang, termasuk Indonesia (Mufidah et al. 2013). Infeksi S. aureus menjadi masalah yang serius saat ini karena meningkatnya resistensi bakteri terhadap berbagai jenis antibiotik (Multi Drug Resistance/MDR). Penggunaan antibiotik secara luas dan tidak rasional menyebabkan problem resistensi. Metisilin-Resisten Staphylococcus aureus (MRSA) dikenal sebagai salah satu bakteri penyebab utama infeksi nosokomial dengan prevalensi rata-rata $50 \%$ (Yuwono, 2009).

Fenomena resistensi bakteri terhadap antibiotik saat ini insidensinya cenderung meningkat di berbagai belahan dunia. Angka kejadian infeksi MRSA di sebagian besar rumah sakit di Asia pada awal tahun 2010 mengalami peningkatan, diantaranya di Hongkong dan di Indonesia 
yaitu 28\%, sedangkan di Korea jauh lebih tinggi yaitu 70\% (Chen and Huang, 2014; Löffler, et al., 2010).

Sistem kekebalan tubuh berperan penting dalam mengatasi infeksi yang disebabkan $S$. aureus. Peptidoglikan $S$. aureus sebagai antigen yang masuk ke dalam tubuh akan menstimulasi fagositosis oleh makrofag. Makrofag, sel dendritik, dan sel lain mengenali mikroba dan memberi respon dengan memproduksi sitokin, yaitu Tumor necrosis factor alfa (TNF $\alpha$ ), Interleukin-1 (IL1), dan Interleukin-6 (IL-6). Sitokin-sitokin ini bekerja mengawali proses migrasi leukosit menuju jaringan untuk eliminasi bakteri. IL-6 menstimulasi hepatosit untuk memproduksi $C$-Reactive Protein yang berkontribusi pada proses inflamasi (Abousouh, et al., 2017; Abbas, et al., 2016; Mufidah, et al., 2013).

Strain MRSA telah diketahui resisten terhadap berbagai antibiotik semua golongan betalaktam dan nonbetalaktam, yaitu makrolida (eritromisin), ampisilin, inhibitor sintesa protein (tetrasiklin, kloramfenikol), dan kuinolon. Antibiotik terpilih untuk terapi MRSA dalam beberapa tahun terakhir ini adalah vankomisin. Penggunaan antibiotik vankomisin masih menjadi pilihan terapi infeksi MRSA (Kumar, et al., 2011; Yuwono, 2009). Saat ini meluasnya resistensi bakteri terhadap obat-obatan yang ada, salah satunya mulai ditemukan strain Vankomisin-Resistant Staphylococcus aureus (VRSA) pada paramedis RSUD Ratu Zulecha Martapura Kalimantan Selatan tahun 2014 (Dwiyanti, et al,. 2015), mendorong pentingnya penggalian sumber antibakteri dari bahan alam atau yang memodulasi respon imun (Mufidah, et al., 2013).

Penelitian terhadap efektivitas anti bakteri MRSA dari bahan alam (Althaea officinalis, Ziziphus jujuba, Cordia latifolia, dan Thymus vulgaris) telah dilakukan, namun hanya Thymus vulgaris yang mampu menurunkan hitung kuman di berbagai organ mencit. Menurut penelitian Arshad, et al., (2017), ekstrak herba timi (Thymus vulgaris) dapat menurunkan indikator infeksi secara hematologi dan menurunkan skoring gambaran lesi patologi anatomi, namun tidak diteliti respon imun dan sitokin yang berperan seperti yang dilakukan pada penelitian ini. Herba timi sangat mudah ditemukan di Indonesia, salah satunya di perkebunan herbal Tawangmangu, Jawa Tengah.

Herba timi dipilih karena mengandung thymol, carvarcrol, terpenoid, flavonoid, dan glikosida, sehingga memiliki efek antibakteri, antivirus, antioksidan, dan immunomodulator. Penelitian Abousouh, et al., (2017), herba timi memiliki efek meningkatkan sitokin IL-12 dan menurunkan hitung kuman pada mencit yang diinfeksi bakteri intraseluler Salmonella thyphi. Penelitian lain yang dilakukan Arshad dkk juga menunjukkan herba timi dapat menurunkan hitung kuman pada mencit yang diinfeksi bakteri MRSA, namun tidak diteliti peningkatan sitokin yang berperan (Arshad, et al., 2017).

Tujuan penelitian ini adalah mengetahui efek ekstrak Thymus vulgaris terhadap kadar IL6 dan hitung kuman mencit balb-c yang diinfeksi MRSA.

\section{METODE}

\section{Alat dan Bahan}

Penelitian ini dilakukan di tiga tempat, selama delapan minggu (Juli 2018 - Agustus 2018). Simplisia daun timi didapatkan dari Balai Besar Penelitian dan Pengembangan Tanaman Obat dan Obat Tradisional (B2P2TOOT) Tawangmangu. Proses pembuatan ekstrak daun timi dilakukan di Unit Pelaksana Teknik-Laboratorium Terpadu (UPT-LT) Universitas Diponegoro, Semarang menggunakan metode maserasi dan vakum evaporator dengan pelarut metanol 96\% (Arshad, et al., 2017); proses infeksi MRSA, perawatan, dan perlakuan (termasuk pengambilan jaringan) 
terhadap hewan coba dilakukan di Laboratorium Parasitologi, Fakultas Kedokteran, Universitas Diponegoro, Semarang; proses pembuatan dan pembacaan preparat hitung kuman dilakukan di Laboratorium Mikrobiologi, Fakultas Kedokteran, Universitas Diponegoro, Semarang. Pemeriksaan kadar IL-6 dengan Enzyme-linked Immunosorbent assay (ELISA) dilakukan di The Center for Biomedical Research (CEBIOR), Universitas Diponegoro, Semarang.

\section{Jalannya Penelitian}

Penelitian ini merupakan penelitian eksperimental dengan desain "Post test only control group design". Subyek penelitian adalah 30 ekor mencit Balb-c jantan yang dibagi secara acak menjadi enam kelompok yang diinfeksi MRSA American Type Culture Collection (ATCC) 43300 $0,2 \mathrm{ml}\left(10^{7} \mathrm{cfu} / \mathrm{ml}\right)$ melalui injeksi intraperitoneal (Luthfita, 2015). Kelompok penelitian dibagi menjadi enam, yaitu kelompok kontrol negatif (K1) yaitu mencit yang diinfeksi tidak diterapi; perlakuan 1 (P1), yaitu mencit diterapi ekstrak timi 7 hari, kemudian diinfeksi MRSA; kontrol positif 1 (K2), yaitu mencit diinfeksi MRSA dan diterapi vankomisin 5mg; perlakuan 2 (P2), yaitu mencit yang diinfeksi diterapi kombinasi ekstrak timi dan vankomisin; kontrol positif 2 (K3), yaitu mencit yang diinfeksi diterapi amoksisilin $1 \mathrm{mg}$; dan perlakuan 3 (P3) yaitu mencit yang diinfeksi diterapi kombinasi ekstrak timi dan amoksisilin. Dosis ekstrak timi yang digunakan adalah 200 $\mathrm{mg} / \mathrm{kgbb} / \mathrm{hari}$ per oral atau 0,3 ml (Arshad, et al., 2017). Kriteria inklusi pada penelitian ini meliputi tikus jantan umur 2 bulan, strain Balb-c yang diinfeksi MRSA, berat badan $\pm 20-30$ gram setelah aklimatisasi selama seminggu di kandang individual, dan tidak ada abnormalitas anatomis yang tampak. Kriteria eksklusi pada penelitian ini adalah jika mencit tampak sakit sebelum diinfeksi bakteri MRSA, sedangkan kriteria drop-out adalah jika selama induksi dan perlakuan, tikus mati.

Variabel bebas adalah dosis ekstrak Thymus vulgaris. Variabel tergantung pada penelitian ini adalah kadar IL-6 dan hitung kuman. Mencit diterminasi pada hari ke 9 perlakuan atau 42 jam setelah diinfeksi MRSA untuk diambil sampel darah dan heparnya (Luthfita, 2015).

\section{Analisis Data}

Data hasil penelitian diolah dan dianalisis menggunakan bantuan perangkat lunak dengan uji $t$-test independent. Analisis data yang dilakukan meliputi analisis deskriptif dan uji hipotesis. Data disajikan dalam bentuk tabel dan grafik, lalu dilakukan uji normalitas dengan uji SaphiroWilk dan uji homogenitas. Uji hipotesis yang digunakan untuk menguji pengaruh pemberian ekstrak Thyme vulgaris terhadap kadar IL-6 adalah uji t-test independent. Uji hipotesis yang digunakan pada hitung kuman di hepar mencit adalah uji Mann Whitney. Batas derajat kemaknaan adalah apabila didapatkan nilai $\mathrm{p} \leq 0,05$.

Penelitian ini menggunakan hewan coba dengan menerapkan animal ethics, yang diperoleh dengan cara pengajuan persetujuan kepada Komisi Etik Penelitian Kesehatan Fakultas Kedokteran Universitas Diponegoro, Semarang, sebelum penelitian dimulai dengan nomor sertifikat 117/EC/H/FK-RSDK/X/2018. 


\section{HASIL}

Tiga puluh ekor mencit Balb-c diadaptasi selama 7 hari dan tidak didapatkan tikus sakit ataupun mati, kemudian dilakukan randomisasi ke dalam 6 kelompok. Empat puluh dua jam setelah diinfeksi MRSA, didapatkan 1 mencit mati pada kelompok K3.

Tabel 1 menunjukkan bahwa rerata kadar IL-6 pada kelompok yang mendapat tambahan terapi ekstrak timi ada yang lebih tinggi daripada pasangannya yang tidak mendapatkan ekstrak Thymus vulgaris (K2-P2), dan ada yang lebih rendah dibandingkan pasangannya yaitu (K-P1) dan (K3-P3). Perbedaan rerata IL-6 antara kelompok K dengan P1, K2 dengan P2, serta K3 dengan P3 tidak bermakna secara statistik $(p=>0,0)$.

Tabel I. Hasil uji t-test independent IL-6

\begin{tabular}{|c|c|c|c|c|c|}
\hline \multicolumn{3}{|c|}{ Perlakuan } & Kelompok & Mean \pm SD & $\mathbf{p}^{\S}$ \\
\hline \multirow{2}{*}{\multicolumn{3}{|c|}{ 1. Kontrol (K) vs ekstrak timi (P1) }} & $\mathrm{K}$ & $687,9 \pm 799,4$ & \multirow{2}{*}{0,086} \\
\hline & & & $\mathrm{P} 1$ & $113,4 \pm 96,7$ & \\
\hline \multirow{2}{*}{$\begin{array}{l}\text { 2. Vankomisin (K2) } \\
\text { ekstrak timi (P2) }\end{array}$} & & \multirow[t]{2}{*}{ Vankomisin+ } & $\mathrm{K} 2$ & $216,6 \pm 111,6$ & \multirow{2}{*}{0,138} \\
\hline & & & $\mathrm{P} 2$ & $492,9 \pm 474,9$ & \\
\hline \multirow{2}{*}{$\begin{array}{l}\text { 3. Amoksisilin (K3) } \\
\text { ekstrak timi (P3) }\end{array}$} & & \multirow{2}{*}{ Amoksisilin+ } & K3 & $402,7 \pm 580,3$ & \multirow{2}{*}{0,692} \\
\hline & & & P3 & $214,8 \pm 119,1$ & \\
\hline
\end{tabular}

Keterangan $:^{\S}$ Independent $\mathrm{t}$

Keterangan : K1= Mencit diinfeksi MRSA dan tidak diterapi, P1= mencit diinfeksi MRSA dan hanya diterapi ekstrak timi, K2= mencit diinfeksi MRSA dan diterapi vankomisin, P2= mencit diinfeksi MRSA dan diterapi kombinasi ekstrak timi, dan vankomisin, K3= mencit diinfeksi MRSA dan diterapi amoksisilin, dan P3= mencit diinfeksi MRSA dan diterapi kombinasi ekstrak timi, dan amoksisilin

Secara umum pada tabel II dapat dilihat median hitung kuman pada kelompok yang mendapat ekstrak timi, lebih rendah dibandingkan dengan kelompok pasangannya yang tidak mendapat ekstrak timi. Nilai median tertinggi didapatkan pada kelompok control, yaitu $36 \times 10^{6}$ cfu dan nilai median terendah didapatkan pada kelompok perlakuan mencit yang diterapi kombinasi ekstrak timi, dan antibiotik baik vankomisin (P2) maupun amoksisilin (P3), yaitu 0 cfu.

Tabel II menunjukkan adanya penurunan tajam hitung kuman dari kelompok kontrol yang tidak mendapatkan terapi, dibandingkan dengan kelompok yang mendapat ekstrak timi, baik sebagai preparat tunggal ataupun kombinasi dengan antibiotik. 
Tabel II. Hasil uji t-test independent hitung kuman di hepar`

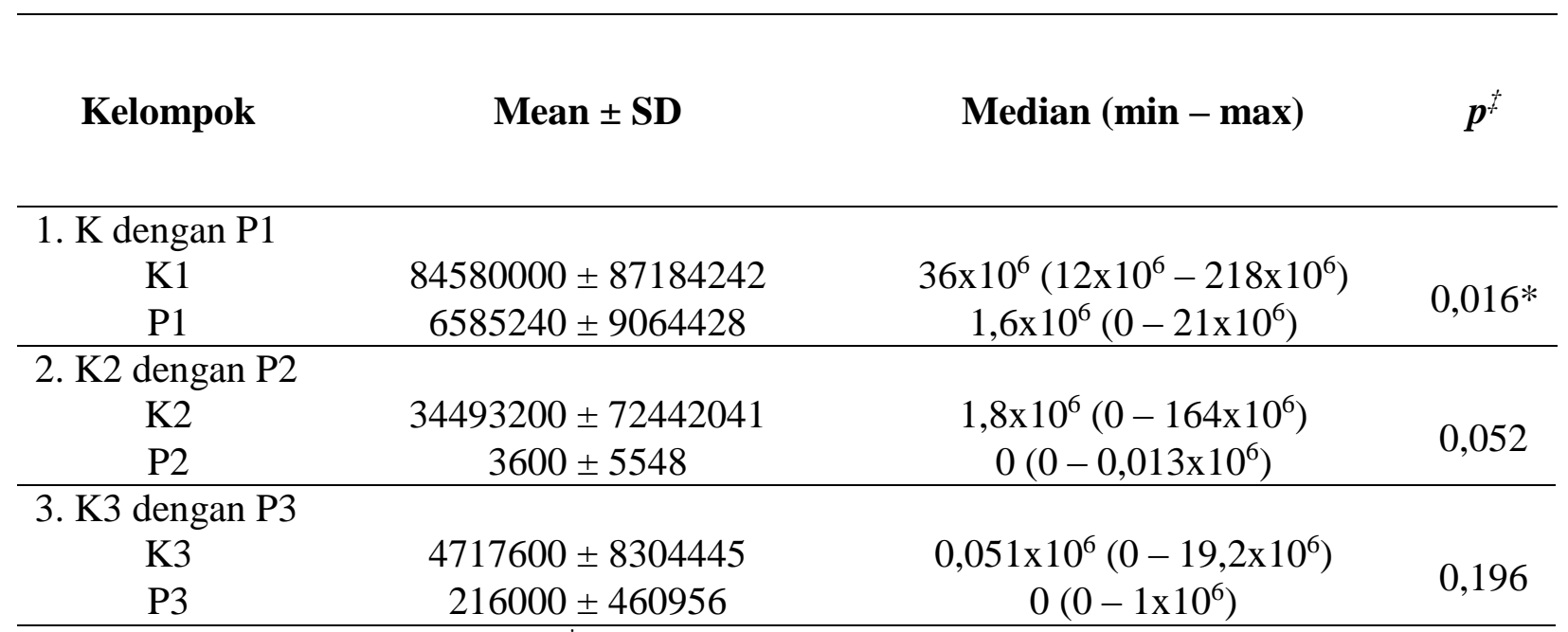

Keterangan : * Signifikan $(p<0,05) ;{ }^{\ddagger}$ Mann whitney

Keterangan : K1= Mencit diinfeksi MRSA dan tidak diterapi, P1= mencit diinfeksi MRSA dan hanya diterapi ekstrak timi,, K2= mencit diinfeksi MRSA dan diterapi vankomisin, P2= mencit diinfeksi MRSA dan diterapi kombinasi ekstrak timi, dan vankomisin, $\mathrm{K} 3=$ mencit diinfeksi MRSA dan diterapi amoksisilin, dan P3= mencit diinfeksi MRSA dan diterapi kombinasi ekstrak timi, dan amoksisilin

Hasil analisis statistik di tabel II didapatkan penurunan jumlah kuman yang bermakna antara K dengan P1 ( $\mathrm{p}=0,016)$. Penurunan jumlah kuman yang lebih besar juga terjadi pada kelompok perlakuan mencit yang diterapi kombinasi ekstrak timi, dan vankomisin (P2) bila dibandingkan dengan kelompok perlakuan yang hanya mendapatkan terapi vankomisin (K2). Hal yang sama juga ditemukan pada kelompok perlakuan mencit yang diterapi kombinasi ekstrak timi, dan amoksisilin (P3) dimana terdapat penurunan jumlah kuman yang lebih besar bila dibandingkan dengan kelompok perlakuan yang hanya diterapi amoksisilin (K3) walaupun tidak bermakna secara statistik.

Uji korelasi yang digunakan pada kadar IL-6dan hitung kuman MRSA adalah uji korelasi Spearman. Hasil uji korelasi Spearman antara variabel didapatkan nilai p 0,659 dan r 0,086, sehingga dapat disimpulkan bahwa terdapat hubungan positif antara IL-6 dan hitung kuman dengan kekuatan korelasi yang sangat lemah.

\section{PEMBAHASAN}

Penelitian ini bertujuan untuk membuktikan pengaruh pemberian ekstrak timi, pada kadar IL-6 dan penurunan hitung kuman pada hepar mencit balb-c yang diinfeksi MRSA. Rerata kadar IL-6 pada kelompok yang mendapat ekstrak timi, ada yang lebih tinggi daripada kelompok pasangannya yang tidak mendapat ekstrak timi,, tetapi ada juga yang lebih rendah daripada pasangannya. Secara statistik tidak dapat disimpulkan bahwa ekstrak timi dapat meningkatkan kadar IL-6. Hal ini kemungkinan karena banyaknya jalur respon imun yang dapat diaktivasi oleh bakteri ekstraseluler. Selain itu, hal yang dapat mempengaruhi lainnya, yaitu lamanya masa pemberian ekstrak timi dan antibiotik yang terlalu pendek dan adanya efek anti bakterial yang kuat dari ekstrak timi (Sienkiewicz, et al., 2011).

Penelitian ini menunjukkan bahwa pemberian ekstrak timi dosis $200 \mathrm{mg} / \mathrm{kgbb} / \mathrm{hari}$ per oral tidak meningkatkan sitokin pro inflamasi IL-6. Hal ini sesuai dengan penelitian lain yang 
menyatakan bahwa ekstrak timi dapat bersifat sebagai anti inflamasi. Hasil penelitian Ocaña and Reglero. G, (2012), menemukan bahwa ekstrak timi dapat menurunkan sitokin pro inflamasi IL1, TNF $\alpha$, dan IL-6, serta menaikkan sitokin anti inflamasi IL-10 pada percobaan in vitro pada makrofag THP-1 yang teroksidasi LDL. Penelitian lain yang dilakukan Kucukgul mendukung hal ini dimana penurunan respon imun terjadi pada kelompok ikan yang diinfeksi Yersinia ruckery dan diterapi minyak esensial thyme (Gulec. A.K, et al., 2013).

Perbedaan sifat ekstrak Thymus vulgaris dalam penelitian ini dengan penelitian lainnya disebabkan oleh cara ekstraksi, komposisi kandungan zat aktif dari setiap varian tanaman timi, dosis ekstrak timi, interaksi timi dengan antibiotik, dan pengaruh efek anti MRSA yang kuat dari ekstrak timi. Hal ini sesuai dengan penelitian lain yang menyatakan bahwa umur tanaman suatu tanaman nilam berpengaruh nyata terhadap komponen metabolit aktif dan hasil tanaman nilam (Hariyani, et al., 2015). Penelitian lain menyatakan pula bahwa minyak esensial tanaman timi memiliki efek anti bakterial terhadap Staphylococcus secara in vitro (Sienkiewicz, et al., 2011).

Penelitian ini ekstraksi dilakukan dengan cara maserasi dengan pelarut metanol $96 \%$, sedangkan pada penelitian lain menggunakan minyak essensial Thymus vulgaris yaitu thymol dan cavacrol yang didapatkan dengan cara ekstraksi dengan distilasi uap konvensional dan SFE (Supercritical Fluid Extraction). Komposisi zat aktif suatu herbal bisa bervariasi menurut jenis varian tanaman, umur tanaman, media pertumbuhan tanaman dan cara ekstraksi. Pada penelitian pendahuluan, efek anti MRSA dari timi telah diuji. Hasil yang didapatkan dari uji MBC, yaitu tidak didapatkan pertumbuhan kuman MRSA pada 1x dan 2x konsentrasi ekstrak Thymus vulgaris yang diuji. Adanya efek anti MRSA yang kuat menyebabkan jumlah kuman dalam tubuh mencit berkurang, sehingga respon inflamasi menjadi lebih kecil. Hal tersebut menjelaskan mengapa kadar IL-6 pada kelompok yang tidak mendapat antibiotik dan tidak mendapat ekstrak timi (K) lebih tinggi daripada kelompok yang mendapat antibiotik, baik diberikan secara tunggal ataupun dikombinasikan dengan ekstrak timi.

Penelitian ini menunjukkan bahwa penurunan median hitung kuman pada kelompok yang mendapat tambahan terapi ekstrak timi lebih besar dibandingkan dengan kelompok pasangan yang tidak mendapat terapi ekstrak timi. Perbedaan penurunan hitung kuman ini bermakna pada pasangan kontrol $(\mathrm{K})$ dan $\mathrm{P} 1(\mathrm{p}<0,05)$ dan tidak bermakna pada pasangan $\mathrm{K} 2$ dan $\mathrm{P} 2(\mathrm{p}>0,052)$ serta pasangan K3 dan P3 ( $\mathrm{p}>0,196)$. Temuan di atas mendukung adanya sifat antibakterial dari ekstrak timi, khususnya terlihat pada kelompok K (tidak diterapi) dan kelompok P1 (terapi ekstrak timi saja). Pada empat kelompok selebihnya juga tampak pengurangan hitung kuman yang lebih besar bila antibiotik dikombinasikan dengan ekstrak timi, walaupun perbedaannya secara statistik tidak bermakna. Hal ini mungkin karena jumlah replikasi sampel terlalu kecil untuk membuktikan perbedaan tersebut secara statistik. Faktor lain adalah masa pemberian antibiotik dan Thymus vulgaris yang terlalu pendek.

Analisis korelasi antara kadar IL-6 dengan jumlah kuman MRSA didapatkan hubungan antara kadar IL-6 dengan hitung kuman MRSA pada organ hepar mencit balb-c namun korelasinya sangat lemah. Hal ini mungkin karena eliminasi kuman MRSA terjadi tidak hanya karena fagositosis yang diperantarai IL-1, IL-6 dan TNF $\alpha$ tetapi juga oleh karena sifat anti bakterial Thymus vulgaris. Penelitian yang dilakukan oleh Sienkiewicz mendukung hal ini dimana minyak esensial Thymus vulgaris memiliki aktivitas anti mikroba terhadap Staphylococcus, Enterococcus, Escherichia secara in vitro (Sienkiewicz, et al., 2011).

Penelitian ini juga menunjukkan hasil bahwa ekstrak timi meningkatkan potensi antibiotik yang diketahui telah resisten sebelumnya. Pemberian kombinasi ekstrak timi dengan amoksisilin dapat meningkatkan efektivitas kerja antibiotik amoksisilin dalam menghambat pertumbuhan 
bakteri MRSA. MRSA telah diketahui resisten terhadap antibiotik amoksisilin (Kumar, et al., 2011; Yuwono 2009). Hal ini terlihat dari rerata jumlah kuman MRSA kelompok perlakuan K3 pada organ hepar mencit balb-c. Jumlah kuman MRSA lebih sedikit ditemukan pada kelompok perlakuan P3 dimana ekstrak timi diberikan bersama antibiotik amoksisilin. Hal ini membuka cakrawala baru bahwa ekstrak timi dapat digunakan untuk melawan resistensi bakteri. Temuan ini mendukung penelitian lain dimana dilaporkan carvacrol bertindak sendiri ataupun kombinasi dengan eritromisin dalam menurunkan jumlah kuman Streptococcus Grup A yang resisten eritromisin, sehingga berpotensi sebagai alat terapeutik baru (Magi, et al., 2015). Penelitian lain menyebutkan berbagai tanaman herbal dapat memiliki aktivitas modifikasi resistensi antibiotik yang ditemukan pada bakteri (Yap et al., 2014). Contohnya, yaitu ekstrak Rosmarinus officinalis dalam melawan bakteri Staphylococcus aureus melalui inhibisi pompa efflux MDR,(Oluwatuyi, et al., 2004) ekstrak Momordica charantia L. dan ekstrak Punica granatum memiliki aktivitas modifikasi resistensi antibiotik pada bakteri MRSA melalui penghambatan pompa efflux (Braga, et al., 2005; Coutinho, et al., 2010).

Konsentrasi ekstrak yang digunakan dalam penelitian ini hanya satu macam yaitu $200 \mathrm{mg} / \mathrm{kgbb} /$ hari, sehingga tidak dapat membandingkan antara efek dosis bertingkat. Kurangnya sampel darah mencit pada penelitian ini tidak memungkinkan untuk dilakukan pemeriksaan darah tepi untuk menghitung jumlah kuman dalam darah. Pada penelitian ini penulis juga menggunakan daun yang komersial dijual bebas, sehingga tidak dapat mengendalikan umur daun timi.s

\section{KESIMPULAN}

Pada penelitian ini dapat disimpulkan bahwa ekstrak timi tidak dapat meningkatkan IL-6 pada mencit balb-c yang diinfeksi MRSA. Terdapat penurunan hitung kuman MRSA yang bermakna pada mencit balb-c yang diinfeksi MRSA dan diterapi Thymus vulgaris dibandingkan dengan yang tidak mendapatkan terapi Thymus vulgaris. Adanya korelasi yang sangat lemah antara kadar IL-6 dengan penurunan jumlah kuman MRSA pada mencit balb-c yang diinfeksi bakteri ekstraseluler MRSA.

\section{UCAPAN TERIMA KASIH}

Ucapan terima kasih kepada Prof. Dr. Edi Dharmana, Sp.PK., M.Sc., Ph.D. yang telah membantu terlaksananya penelitian ini, serta kepada seluruh staf dan teknisi Laboratorium Mikrobiologi Fakultas Kedokteran Universitas Diponegoro dan Laboratorium GAKI Fakultas Kedokteran Universitas Diponegoro, sehingga penelitian ini dapat terlaksana

\section{DAFTAR PUSTAKA}

Abbas, A.K., Lichtman, A.H., Pillai, S. 2016. Basic Immunology : Functions and Disorders of the Immune System. 5 ed. W.B Saunders Company. Philadelphia.

Abousouh, S., Widjajanto, E., Sujuti, H. 2017. Effect of Thymus vulgaris extract on level of serum , Il12 and bacterial colonies in liver in mice infected by Salmonella typhimurium. International Journal of ChemTech Research 10(9): 881-86.

Arshad, N., Mehreen, A., Liaqat, I., Arshad, M., Afrasiab, H. 2017. In vivo screening and evaluation of four herbs against MRSA infections. BMC Complementary and Alternative Medicine 17: 1-7. 
Braga, L.C., Leite, A.A., Xavier, K.G., Takahashi, J.A., Bemquerer, M.P., Chartone-Souza, E., et al. 2005. Synergic interaction between pomegranate extract and antibiotics against Staphylococcus aureus. Canadian Journal of Microbiology 51(7): 541-7.

Chen, C.J., Huang, Y.C. 2014. New epidemiology of Staphylococcus aureus infection in Asia. (Themed Section: New epidemiology of Staphylococcus aureus infections.). Clinical Microbiology and Infection 20(7): 605-23.

Coutinho, H.D., Costa, J.G., Falcao-Silva, V.S., Siqueira-Junior, J.P., Lima, E.O. 2010. Effect of Momordica charantia L. in the resistance to aminoglycosides in methicilin-resistant Staphylococcus aureus. Comparative immunology, microbiology and infectious diseases 33(6): 467-71.

Dwiyanti, R.D., Muhlisin, A., Muntaha, A. 2015. MRSA Dan VRSA pada paramedis RSUD Ratu Zalecha Martapura. Medical Laboratory Technology Journal 1(1):27-33.

Gulec, A.K, Kucukgul, A., Danabas. D., Ural, M., Seker, E., Arslan, A., et al. 2013. Therapeutic effects of thyme (thymus vulgaris linneaus) and fennel (foeniculum vulgare miller) essential oils in infected rainbrow trout, oncorhynchus mykiss (walbaum). Digest Journal of Nanomaterials and Biostructures 8(3): 1069-78.

Hariyani, Widaryanto, E., Herlina, E. 2015. Pengaruh umur panen terhadap rendemen dan kualitas minyak atsiri tanaman Nilam (Pogostemon cablin Benth.). Jurnal Produksi Tanaman. Universitas Brawijaya 3(3): 205 - 11.

Kumar, R., Yadav, B.R., Singh, R.S. 2011. Antibiotic resistance and pathogenicity factors in Staphylococcus aureus isolated from mastitic Sahiwal cattle. Journal of Biosciences 36(1): 175-88.

Löffler, B., Hussain, M., Grundmeier, M., Brück, M., Holzinger, D., Varga, G., et al. 2010. Staphylococcus aureus panton-valentine leukocidin is a very potent cytotoxic factor for human neutrophils. PLoS Pathogens 6(1): 1-12.

Luthfita, A. 2015. Pengaruh pemberian minyak Nigella sativa dan kombinasinya dengan seftriakson terhadap jumlah kuman MRSA pada kultur hati mencit balb-c. Semarang : Fakultas Kedokteran Universitas Diponegoro.

Magi, G., Marini, E., Facinelli, B. 2015. Antimicrobial activity of essential oils and carvacrol, and synergy of carvacrol and erythromycin, against clinical, erythromycin-resistant Group A Streptococci. Frontiers in microbiology 6: 165.

Mufidah, Z., Rifa'i, M., Rahayu, S. 2013. Aktivitas Imunomodulator ekstrak buah Mengkudu pada mencit yang diinfeksi Staphylococcus aureus. Jurnal Veteriner 14(4): 501-10. 
Ocaña, A., Reglero, G. 2012. Effects of Thyme extract oils (from Thymus vulgaris, Thymus zygis, and Thymus hyemalis) on cytokine production and gene expression of oxldl-stimulated thp-1-macrophages. Journal of Obesity 2012:1-11.

Oluwatuyi, M., Kaatz, G.W., Gibbons, S. 2004. Antibacterial and resistance modifying activity of Rosmarinus officinalis. Phytochemistry 65(24): 3249-54.

Sienkiewicz, M., Lysakowska. M., Ciecwierz, J., Denys, P., Kowalczyk, E. 2011. "Antibacterial activity of thyme and lavender essential oils. Med Chem 7(6):674-689.

Yap, P.S., Yiap, B.C., Ping, H.C., Lim, S.H. 2014. Essential oils, a new horizon in combating bacterial antibiotic resistance. The Open Microbiology Journal 8: 6-14.

Yuwono. 2009. Staphylococcus aureus dan Methicillin Resistant Staphylococcus aureus (MRSA). Departemen Mikrobiologi FK Unsri. Palembang. 